\title{
MENDUKUNG UPAYA PERLINDUNGAN PENYU BELIMBING (Dermochelys coriacea) MELALUI PENDIDIKAN (PROGRAM KKN WAU-WEYAF, ABUN)
}

\section{Supporting the Leatherback Turtle (Dermochelys coriacea) Protection Effort through Education Approach (Wau-Weyaf, Abun KKN Program)}

\author{
Freddy Pattiselanno ${ }^{1)^{*}}$, Natanael Natumnea ${ }^{2)}$, Kuswanto $^{3)}$, Muhamad Ansarudin ${ }^{4)}$, Yosefina \\ M. Goban ${ }^{5)}$, Evi S.H. Kararbo ${ }^{6)}$, Martha Kayadoe ${ }^{6)}$, Eli F. Karubaba ${ }^{7)}$ \\ ${ }^{1)}$ Prodi Budidaya Ternak Fakultas Peternakan Universitas Papua \\ ${ }^{2)}$ Prodi Teknik Informatika Fakultas Teknik Universitas Papua \\ ${ }^{3)}$ Prodi Teknik Pertambangan Fakultas Teknik Pertambangan \& Perminyakan Universitas Papua \\ ${ }^{4)}$ Prodi Pendidikan Fisika Fakultas Keguruan \& Ilmu Pendidikan Universitas Papua \\ ${ }^{5}$ Prodi Pendidikan Biologi Fakultas Keguruan \& Ilmu Pendidikan Universitas Papua \\ ${ }^{6)}$ Program Studi Nutrisi dan Teknologi Pakan Ternak Fakultas Peternakan Universitas Papua \\ ${ }^{7)}$ Program Studi Ekonomi Pembangunan Fakultas Ekonomi \& Bisnis Universitas Papua
}

Article history

Received: Apr 08, 2021;

Accepted: May 20, 2021

* Corresponding author:

E-mail:

f.pattiselanno@unipa.ac.id

DOI: https://doi.org/10.465

49/igkojei.v2i2.209

\begin{abstract}
Wau-Weyaf Beach is the nesting ground of six species of turtles, including the world's largest turtle, the leatherback turtle (Dermochelys coriacea). The University of Papua (UNIPA) Manokwari, since 2009 has been directly involved in the turtle nesting area protection program by involving the students of UNIPA through the Community Service Program (KKN). In 2016, students carried out the KKN Program starting from June 30th to August 16th in Kampung WauWeyaf, one of the leatherback turtles' egg-laying locations in Abun. This paper is a part of the Community Service Program which is carried out in the said village. The activities conducted during the KKN include both formal and non-formal education, religious education, and environmental education. Education-based $K K N$ directly helps to improve public awareness which, in turn, supports the efforts to protect and save the leatherback turtles (Dermochelys coriacea) on the coast of Abun, Tambrau. The same approach is also able to improve the calistung (the capability to read, write, and count) ability of school children along with their awareness to maintain the cleanliness of their homes, school, and village environment.
\end{abstract}

Keywords: Education; Conservation; Turtle; Wau-Weyaf

\section{ABSTRAK}

Pantai Wau-Weyaf merupakan tempat bertelur bagi 6 jenis penyu, termasuk penyu terbesar di dunia, Penyu Belimbing (Dermochelys coriacea). Universitas Papua (UNIPA) Manokwari, sejak tahun 2009 telah terlibat secara langsung dalam program perlindungan kawasan peneluran penyu ini melalui pelibatan mahasiswa melalui program Kuliah Kerja Nyata (KKN). Pada tahun 2016, mahasiswa Universitas Papua (UNIPA) melaksanakan program KKN yang dilaksanakan antara tanggal 30 Juni sampai dengan 16 Agustus 2016 di Kampung Wau-Weyaf. Tulisan ini merupakan bagian dari pelaksanaan kegiatan KKN yang dilaksanakan di kampung Wau-Weyaf sebagai salah satu lokasi peneluran telur penyu belimbing di Abun. Kegiatan yang dilakukan meliputi pendidikan formal dan non-formal, pendidikan agama, dan pendidikan lingkungan. KKN berbasis pendidikan yang dilakukan secara langsung membantu meningkatkan penyadar 
Pattiselanno et al. Mendukung Upaya Perlindungan Penyu Belimbimg (Dermochelys coriacea)

tahuan masyarakat yang menunjang usaha perlindungan dan penyelamatan penyu belimbing (Dermochelys coriacea) di pesisir Abun, Tambrau. Pendekatan yang sama juga mampu meningkatkan kemampuan calistung anak-anak sekolah dan kesadaran menjaga kebersihan lingkungan rumah, sekolah dan kampung.

Kata kunci: Pendidikan; Konservasi; Penyu; Wau-Weyaf

\section{PENDAHULUAN}

Surat Keputusan Bupati Sorong No.142 tahun 2005 bahwa Taman Wisata Laut Distrik Abun sebelumnya ditetapkan sebagai Kawasan Konservasi Laut Daerah (KKLD) dengan luas 169.515,783 Ha. Terdiri dari luas daratan 69.179,38 Ha dan laut seluas 99.179,38 Ha. Pantai pada taman wisata ini dengan panjang $121.381 \mathrm{~km}$ menjadi tempat bertelur bagi 6 jenis penyu, termasuk penyu terbesar di dunia, Penyu Belimbing (Dermochelys coriacea) (KKP, 2015). Di Papua Barat, Kawasan Konservasi Perairan Daerah (KKPD) di Kabupaten Kaimana, seluas 597.747 hektar, juga telah ditetapkan berdasarkan Peraturan Bupari Kaimana No. 4 Tahun 2012.

Universitas Papua (UNIPA) Manokwari, sejak tahun 2009 telah terlibat secara langsung dalam program perlindungan kawasan peneluran penyu ini melalui program-program konservasi penyu belimbing dan pemberdayaan masyarakat yang disertai dengan pelatihan-pelatihan berkelanjutan yang juga bertujuan mensejahterakan kehidupan masyarakat sampai dengan saat ini (Karabo et al., 2016). Oleh karena itu program pendampingan di kampung binaan di pesisir Kabupaten Tambrauw secara berkala tetap menjadi prioritas program pemberdayaan oleh UNIPA. Salah satu program yang dilakukan adalah pelibatan mahasiswa melalui program Kuliah Kerja Nyata (KKN) (Pattiselanno et al., 2018).

Melalui pendekatan pendidikan masyarakat khususnya anak-anak, program KKN ini bertujuan untuk meningkatkan kesadaran, aktif berpartisipasi dan secara aktif dalam usaha perlindungan hidupan liar yang ada, termasuk penyu belimbing. Tulisan ini merupakan bagian dari pelaksanaan kegiatan KKN yang dilaksanakan di Kampung Wau-Weyaf sebagai salah satu lokasi peneluran telur penyu belimbing di Abun.

\section{METODE}

Makalah ini merupakan bagian dari pelaksanaan KKN oleh mahasiswa UNIPA yang dilaksanakan selama 3 bulan di Kampung Wau-Weyaf, Distrik Abun, Kabupaten Tambrau (Gambar $1)$. 


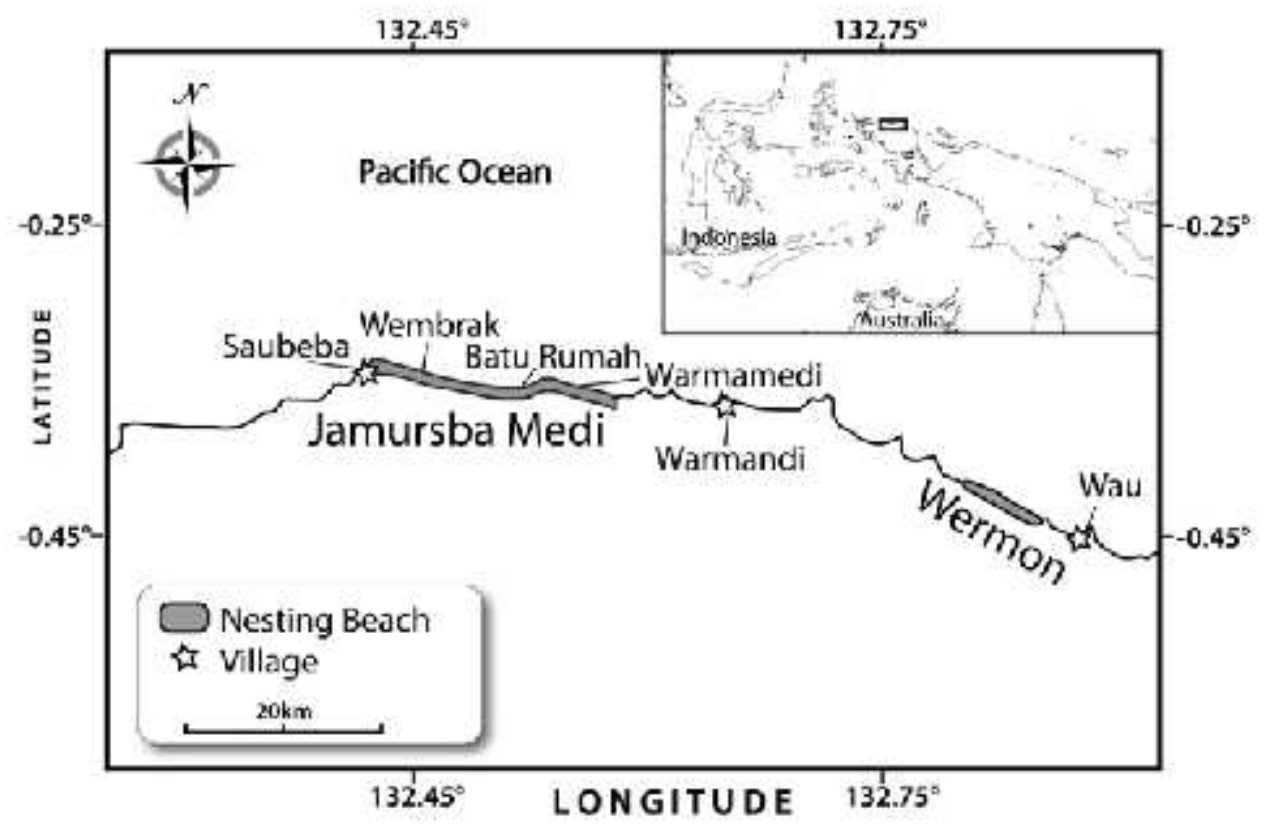

Gambar 1. Peta lokasi KKN di Kampung Wau-Weyaf

Sebelum melaksanakan kegiatan, mahasiswa terlebih dahulu dibekali dengan kuliah pesangon berkaitan dengan rencana program yang dilaksanakan selama program KKN. Sebanyak lima orang mahasiswa tergabung dalam kelompok KKN Wau-Weyaf, sesuai dengan bidang ilmu mereka masing-masing. Rencana program kerja direncanakan sejak awal pada saat pembekalan program kerja menurut acuan KKN di UNIPA (Pattiselanno et al., 2016b).

Setelah pertemuan secara resmi dengan masyarakat dan aparat desa, mahasiswa menyampaikan rencana program yang sudah disiapkan. Secara keseluruhan program yang diusulkan didiskusikan dengan masyarakat untuk mendapatkan persetujuan pelaksanaan bersama dengan masyarakat. Terdapat program yang tidak dapat dilaksanakan karena kondisi di lapangan tidak memungkinkan tetapi ada usulan program dari masyarakat yang dimasukan menjadi program kerja bersama dengan masyarakat.

Pertemuan dengan masyarakat telah disepakati bahwa program perlindungan penyu diakomodir dalam bidang lingkungan, keagamaan dan pendidikan. Di bidang lingkungan yaitu dengan melakukan pembersihan lokasi peneluran penyu, di bidang keagamaan yaitu tentang peran makhluk hidup dalam kehidupan, serta bidang pendidikan yaitu melalui pendidikan pengetahuan alam dan calistung. Metode pelaksanaan yaitu melalui ceramah, observasi di lapangan dan praktek dalam kehidupan sehari-hari. 
Pattiselanno et al. Mendukung Upaya Perlindungan Penyu Belimbimg (Dermochelys coriacea)

\section{HASIL DAN PEMBAHASAN}

\section{SOSIALISASI DAN PENYUSUNAN PROGRAM}

Berdasarkan Pola Ilmiah Pokok UNIPA dan Satuan Operasional Prosedur, Program KKN UNIPA terdiri dari 8 bidang program kerja yaitu 1). Kesehatan, 2). Administrasi Kampung, 3). Peternakan, 4). Pertanian, 5). Lingkungan, 6). Keagamaan, 7). Pendidikan, dan 8). Ekonomi Sosial budaya (LPPM UNIPA, 2020).

Mengingat karakteristik lokasi KKN dan tujuan utama pelaksanaan KKN di Wau-Weyaf, setelah berdiskusi dengan masyarakat, semua program dapat diakomodir dalam kegiatan bersama mahasiswa dan masyarakat dengan mengacu pada kondisi kampung (Gambar 2).

Secara rinci dalam tulisan ini, fokus pembahasan hanya dibatasi pada bidang pendidikan sebagai tema sentral dalam mendukung upaya konservasi di kawasan pesisir Abun. Bidang pendidikan dimaksud termasuk pendidikan formal dan non-formal sehingga pendidikan di bidang keagamaan dan lingkungan hidup juga menjadi bagian pembahasan.

\section{PENDIDIKAN FORMAL DAN NON-FORMAL}

Pendidikan formal dilakukan dalam bentuk mengajar siswa di SD. INPRES 36 Wau. Bersama dengan tim guru dan kepala sekolah, mahasiswa KKN membantu para guru dalam membaca, tulis dan hitung (calistung) bagi para siswa yang kemampuan calistung mereka masih sangat rendah.

Aktifitas ini berlangsung setiap hari. Jumlah peserta didik yang terlibat dalam kegiatan ini antara 20-30 orang siswa, dan semua mahasiswa KKN secara bergantian sesuai jadwal terlibat membantu para siswa. Pada awal kegiatan memang anak-anak agak kesulitan dalam menyesuaikan diri dengan bahan bacaan dan perhitungan yang disiapkan. Tetapi para mahasiswa dengan telaten dan sabar menuntun anak-anak selama proses berlangsung. Setelah minggu pertama, peserta didik dapat menyesuaikan diri dan aktivitas berjalan dengan baik.

Dalam kaitan dengan perlindungan penyu melalui kunjungan lapang anak-anak dilatih untuk menghitung jumlah sarang, serta deskripsi singkat kondisi sarang yang nantinya diceritakan di kelas pada saat pertemuan. Dalam kegiatan di kelas, para murid dilatih untuk menulis tentang penyu dan lingkungan sekitar. Orang tua dan guru menyambut positif kegiatan ini, karena dampaknya terlihat langsung dalam kemampuan calistung anak-anak.

Selain membantu mengajar secara formal di sekolah, para mahasiswa KKN juga ikut membantu mengajar informal di Posko KKN (Gambar 3a) dalam bentuk bimbingan belajar. Tujuan kegiatan ini yaitu untuk meningkatkan kemampuan anak yang sudah baik dan mengasah kemampuan anak yang masih kurang. Hal yang paling mendasar yang dilakukan adalah memperkenalkan huruf, angka serta belajar membaca, menulis dan menghitung bagi para siswa. Pengenalan gambar satwa yang hidup di laut, termasuk penyu juga merupakan bagian dari usaha perlindungan penyu. Di akhir proses 
pembelajaran, anak-anak memperoleh pengertian yang lebih baik terhadap pentingnya menjaga lingkungan hidup dan keberadaan satwa di sekitar kita.

\begin{tabular}{|c|c|c|}
\hline Faktor Penghambat & $\begin{array}{c}\text { Tindakan yang } \\
\text { dilakukan }\end{array}$ & $\begin{array}{c}\text { Capaian yang } \\
\text { diperoleh }\end{array}$ \\
\hline $\begin{array}{l}\text { Jumlah guru \& } \\
\text { ketersediaan bahan } \\
\text { ajar terbatas } \\
\text { Waktu anak tersita } \\
\text { membantu orang tua } \\
\text { di luar jam sekolah } \\
\text { Kurang motivasi } \\
\text { penyemangat anak }\end{array}$ & $\begin{array}{l}\text { Membantu proses } \\
\text { belajar mengajar } \\
\text { Menyelenggarakan } \\
\text { bimbingan belajar } \\
\text { Menyediakan alat bantu } \\
\text { hitung } \\
\text { Melakukan kegiatan } \\
\text { pendidikan lingkungan }\end{array}$ & $\begin{array}{l}\text { Kemampuan } \\
\text { Calistung meningkat } \\
\text { Tersedianya alat } \\
\text { bantu hitung bagi } \\
\text { anak } \\
\text { Lingkungan yang } \\
\text { lebih tertata dengan } \\
\text { baik }\end{array}$ \\
\hline
\end{tabular}

Gambar 2. Deskripsi faktor penghambat, tindakan yang dilakukan dan capaian yang diperoleh

Kegiatan dilaksanakan oleh para mahasiswa dengan guru mulai tanggal 25 Juli sampai dengan 13 Agustus 2016. Dibutuhkan kesabaran para mahasiswa dalam membimbing anak-anak. Hal ini cukup beralasan karena sebelumnya anak-anak banyak menghabiskan waktu dengan bermain, sehingga butuh waktu untuk mengalihkan perhatian mereka melalui kegiatan bimbingan belajar. Selingan bermain di antara belajar dalam bentuk latihan dan kuis, meningkatkan minat anak-anak untuk terlibat aktif. Sampai dengan berakhirnya program KKN, minat anak-anak dibimbing oleh mahasiswa tetap tinggi.

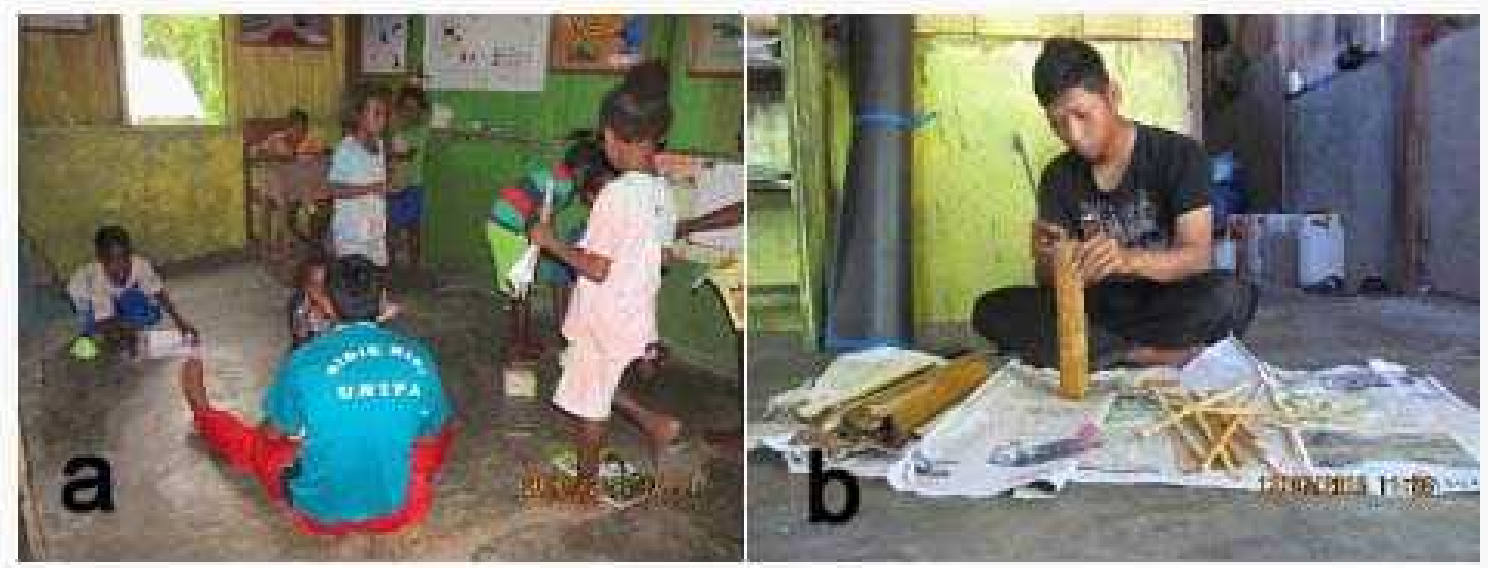

Gambar 3. (a) Proses bimbingan belajar, (b). Pembuatan alat bantu hitung

Guna membantu proses belajar mengajar, diperlukan alat bantu supaya kegiatan dapat berjalan dengan baik. Salah satu upaya yang dilakukan adalah menyediakan alat bantu hitung dari bahan yang ada di sekitar (Gambar 3b). Ketersediaan alat bantu hitung diharapkan akan membantu anak-anak dalam menghitung. Melalui pemanfaatan bahan yang ada di sekitar, mahasiswa menyediakan alat 
Pattiselanno et al. Mendukung Upaya Perlindungan Penyu Belimbimg (Dermochelys coriacea)

bantu hitung yang dibuat dari bambu. Hal ini disambut positif oleh guru dan anak-anak, karena hal ini sangat membantu meningkatkan kemampuan berhitung anak-anak.

\section{PENDIDIKAN AGAMA}

Program pendidikan agama terdiri dari dua kegiatan yaitu mengasuh Sekolah Minggu, yang dilakukan setiap hari Minggu selama bulan Juli sampai dengan Agustus 2016 bertempat di gedung SD Inpres 36 Wau. Kegiatan mengasuh Sekolah Minggu dilakukan jam 08.00 - 09.00 pagi. Kegiatan ini diikuti oleh 20-25 orang anak. Sedangkan kegiatan mengasuh Tunas anak Sekolah Minggu GKI Imanuel Wau dilakukan setiap hari Senin selama bulan Juli sampai dengan Agustus 2016. Kegiatan dimulai jam 16.00 - 17.30 WIT di posko KKN Wau-Weyaf yang diikuti oleh 10-15 orang anak.

Minat anak-anak cukup tinggi, dan respon orang tua sangat baik terhadap kegiatan yang dilakukan. Hal positif yang diperoleh yaitu, kemampuan baca anak ikut meningkat melalui kegiatan pendidikan kerohanian ini. Ketersediaan bahan bacaan yang berwarna juga membuat anak-anak tertarik dan berminat untuk membaca bahan bacaan yang disediakan.

Dalam kegiatan pendidikan agama ini, juga disisipkan pesan moral, pentingnya anak-anak memiliki akhlak dan moral yang baik. Selain itu juga, pendidikan agama ini mengajar anak untuk menjaga lingkungan dan makhluk hidup yang juga adalah ciptaan Tuhan. Di akhir pembelajaran, anak-anak memahami dengan baik hidup berdampingan dengan makhluk hidup lainnya.

\section{PENDIDIKAN LINGKUNGAN}

Program pendidikan lingkungan yang dilakukan terdiri dari (1) Kerja Bakti bersama anak sekolah sekaligus penanaman pagar hidup di sekolah setiap dua minggu sekali, (2) Pembersihan lingkungan sekitar kampung termasuk lokasi peneluran penyu, setiap dua minggu sekali selama kegiatan KKN (Gambar 4a), dan (3) Pemeliharaan sumber air bersih di kampung Wau-Weyaf pada tanggal 31 Agustus 2016 (Gambar 4b).

Capaian yang diperoleh dari program ini adalah lingkungan sekolah dan kampung terpelihara kebersihannya. Peningkatan kesadaran bagi anak-anak dan warga kampung peran kebersihan lingkungan dalam mendukung kebersihan lingkungan berkelanjutan. Kondisi sekitar sekolah dan kampung tertata dengan baik dan kebersihannya tetap terjaga. Menjaga kebersihan lingkungan sekitar tempat tinggal dan sekolah juga kawasan peneluran pada akhirnya menjadi program tetap di kampung sebagai upaya mendukung lingkungan yang sehat. 


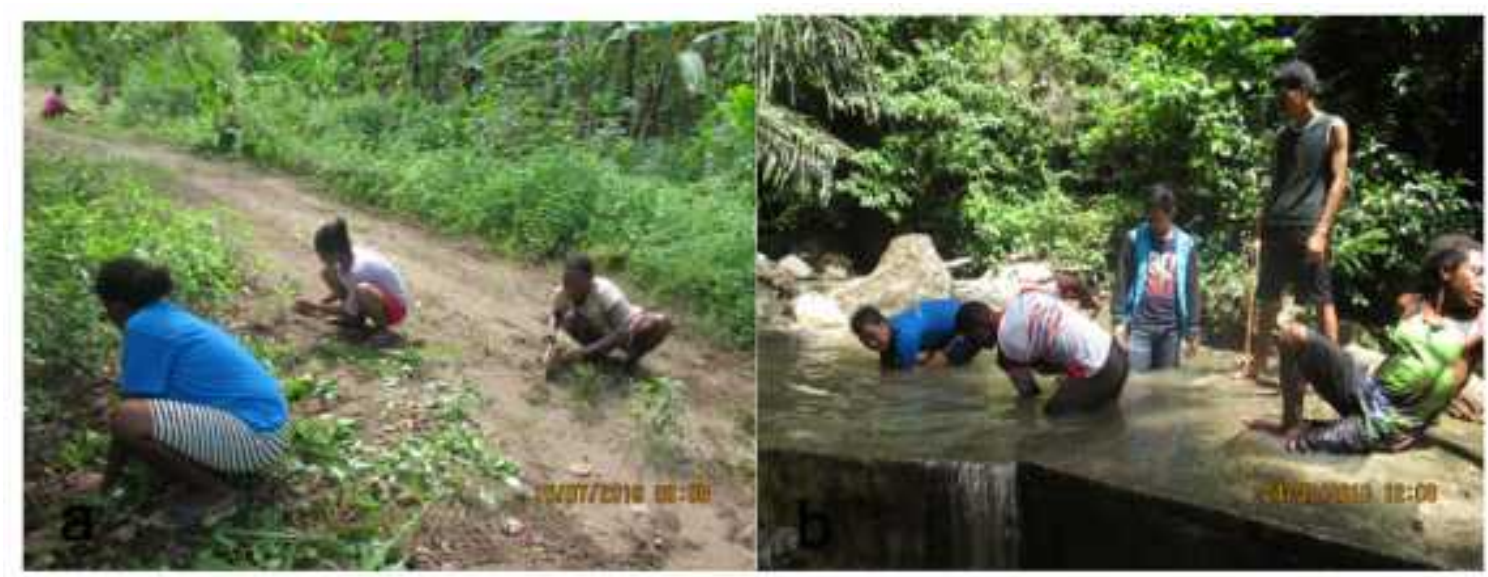

Gambar 4. (a). Kerja Bakti pembersihan lingkungan kampung, (b). Kegiatan pemeliharaan sumber air bersih di Kampung Wau-Weyaf

\section{KESIMPULAN}

Kegiatan Kuliah Kerja Nyata $(\mathrm{KKN})$ berbasis pendidikan yang dilakukan di kampung WauWeyaf secara langsung membantu meningkatkan penyadar tahuan masyarakat akan pentingnya usaha perlindungan dan penyelamatan penyu belimbing (Dermochelys coriacea) di pesisir Abun, Tambrau. Secara tidak langsung pendekatan pendidikan berdampak terhadap kemampuan calistung anak-anak sekolah dan kesadaran menjaga kebersihan lingkungan rumah, sekolah dan kampung.

\section{UCAPAN TERIMA KASIH}

Ucapan terima kasih disampaikan kepada Pimpinan Lembaga Penelitian \& Pengabdian Pada Masyarakat Universitas Papua. Program Pendampingan Masyarakat Pesisir LPPM-COE ikut membantu dalam pelaksanaan kegiatan KKN ini. Penghargaan dan ucapan terima kasih disampaikan kepada Aparat Kampung dan warga masyarakat Kampung Wau-Weyaf yang telah menerima kami dan membantu sehingga program KKN ini dapat terlaksana dengan baik.

\section{DAFTAR PUSTAKA}

Karabo, E., Goban, Y., Ansarudin, M., Kuswanto, Natumnea, N., Pattiselanno, F. 2016. Konservasi Penyu Belimbing Berbasis Pendidikan di Kepala Burung Papua. Warta Konservasi Lahan Basah Vol. 24(3); 4-5.

Kementerian Kelautan dan Perikanan - KKP. 2015. Profil Kawasan Konservasi Papua dan Papua Barat. Direktorat Konservasi Kawasan dan Jenis Ikan Direktorat Jenderal Kelautan, Pesisir dan Pulau-Pulau Kecil Kementerian Kelautan dan Perikanan

Lembaga Penelitian \& Pengabdian Pada Masyarakat. 2020. Panduan KKN Merdeka Belajar UNIPA Tahun 2020. LPPM Universitas Papua, Manokwari.

Pattiselanno, F., Wondikbo, A., Emaury, A., Farwas, A., Rumayomi, I., Towansiba, N. 2016. Pengabdian Pada Masyarakat di Pesisir Kepala Burung: Pembelajaran dari Kampung Saubeba di Tambrau, Propinsi Papua Barat. Prosiding Seminar Nasional Lahan Basah Tahun 2016, Jilid 3. Hal: 1990-1993.

Pattiselanno, F., Wondikbo, A., Emaury, A., Farwas, A., Rumayomi, I., Towansiba, N. 2018. Program Pemberdayaan Masyarakat Pesisir Berbasis Pendidikan di Saubeba-Abun, Papua Barat.Buletin Udayana Mengabdi Vol. 17(1): 169-176. 